\title{
SEPARATION OF POWERS: JUDICIAL INDEPENDENCE
}

\author{
SAM J. ERVIN, JR.*
}

I

The Historical Perspective

When the Founding Fathers gathered in Philadelphia in $x 787$ to draft the United States Constitution, the concept of separation of powers was a fundamental political maxim which dominated the thinking of many of the members of the Constitutional Convention. A substantial number of the draftsmen arrived predisposed toward creating a government separated into three co-equal branches-the executive, the legislative, and the judicial.

The separation of powers doctrine grew out of centuries of political and philosophical development. Its origins can be traced to the fourth century B.C. when Aristotle, in his treatise entitled Politics, described three agencies of government: the general assembly, the public officials, and the judiciary. ${ }^{1}$ In republican Rome, there was a somewhat similar system consisting of public assemblies, the senate, and the public officials, all operating on a principle of checks and balances. ${ }^{2}$ Following the fall of the Roman Empire, Europe became fragmented into nation-states, and from the end of the Middle Ages until the eighteenth century the dominant governmental structure consisted of a concentrated power residing in hereditary rulers, the sole exception being the developmentof the English Parliament in the seventeenth century. With the birth of Parliament, the theory of three branches of government reappeared, this time embodied in John Locke's Two Treatises of Government ( $\mathrm{I} 68 \mathrm{9}$ ), where these three powers were defined as "legislative," "executive," and "federative." Locke, however, did not consider the three branches to be co-equal, nor were they designed to operate independently. ${ }^{5}$ Locke considered the legislative branch to be supreme, while the executive and federative functions-internal and external affairs, respectively-were left within the control of the monarch, a scheme which obviously corresponded with the dual form of government prevailing in England at the time, the Parliament and the King. ${ }^{\circ}$

The doctrine was refined and expanded by Baron de Montesquieu, whose Spirit

- United States Senator from North Carolina.

${ }^{1}$ ARIstotLe, Politics, book IV, ch. 14. See generally Robinson, The Division of Governmental Power in Ancient Greece, 18 PoL. Scr. Q. 6I4 (rg03).

2 J. Bryce, Modern Democractes $39 \mathrm{I}$ (I92I).

${ }^{8}$ See generally Fairlie, The Separation of Powers, 2r Mrah. L. REv. 393 (1922).

'J. Locke, Treatise of Civil Government and Letter Concerning Toleration 97-99 (Sherman ed. 1937).

Id.

Fairlie, supra note 3 , at 396. 
of the Laws appeared in 1748 and was well known to many members of the Constitutional Convention. The Frenchman based his theory on his understanding of the English system, which, since the time of Locke, had generated a more independent judiciary and a tendency toward a greater distinction among the three branches. In discussing the importance of clear delineations of power among the three branches, Montesquieu wrote:

When the legislative and executive powers are united in the same person or body, there can be no liberty, because apprehension might arise lest the same monarch or senate should enact tyrannical laws, to execute them in a tyrannical manner.

Again, there is no liberty, if the judiciary power be not separate from the legislative and executive. Were it joined with the legislative, the life and liberty of the subject would be exposed to arbitrary control; for the judge would be then the legislator. Were it joined to the executive power, the judge might behave with violence and oppression.

There would be an end of everything, were the same man or the same body, whether of the nobles or the people, to exercise those three powers, that of enacting the laws, that of executing the public resolutions, and of trying the cases of individuals. ${ }^{7}$

Montesquieu also observed that, in the British system, the judiciary ranked "next to nothing" when compared with the other branches of government. ${ }^{8}$ Some seventeen years later, Blackstone noted the importance of a more powerful and independent judiciary in his Commentaries, which were a primary reference for the American colonists:

Were it [the judicial power] joined with the legislative, the life, liberty and property, of the subject would be in the hands of arbitrary judges, whose decisions would be then regulated only by their own opinions, and not by any fundamental principles of law; which, though legislators may depart from, yet judges are bound to observe. Were it joined with the executive, this union might soon be an overbalance for the legislative. ${ }^{9}$

Just two years before the Constitutional Convention, William Paley, the English philosopher and theologian, observed in his Moral and Political Philosophy:

[T] he judges of the land become not infrequently the arbitrators between the king and the people, on which account they ought to be independent of either; or, what is the same thing, equally dependent upon both; that is, if they be appointed by one, they should be removable only by the other..$^{10}$

\footnotetext{
${ }^{7}$ I B. DE MONTESQUIEU, SPIRTt of the LATS I52 (Nugent ed. I823).

${ }^{8} I d$. at 156 .

- W. Blackstone, Comamentaries on the Laws of England 259-60 (I765). An unexplained and undocumented note found inside one of the 1765 editions in the Library of Congress proclaimed, "By the year 1776 nearly 2,500 copies of Blackstone's Commentaries were in use in the Colonies, of which I, 500 were of the first American edition exhibited above. This circumstance led Burke, in moving his resolution for conciliation with the Colonies, to declare: T hear that they have sold nearly as many of Blackstone's Commentaries in America as in England.' "

${ }^{10}$ W. Paley, Moral and Political Philosophy 345 (1824).
} 
Thus the doctrine of separation of powers, including an independent judiciary, was reasonably well developed by 1787 when the framers of the Constitution met, and its incorporation into the document they hoped to draft was of paramount consideration to them. It was a doctrine of such broad importance that it had been treated by scores of writers, and discussed by knowledgeable men throughout the colonies. It is doubtful that many members of the Constitutional Convention arrived in Philadelphia completely unaware of its impact. Beyond the theoretical importance of the doctrine, the founding fathers had learned a difficult lesson during their first attempt at government under the Articles of Confederation, which had made "virtually no concession" to the principle. ${ }^{11}$ That attempt at national government, as any student of American history knows, was not an unqualified success. To correct the shortcomings of the Articles, while at the same time providing checks against tyranny, the founding fathers turned to the doctrine of separation of powers, including an independent judiciary.

\section{A. English Precedents}

Many of the men who attended the Constitutional Convention were lawyers, and virtually all of them were familiar with the centuries-old struggle for judicial independence in England. From what they accomplished, it is clear that one of their overriding purposes in applying the doctrine of separation of powers to the new Constitution was to carry that struggle to fruition.

Before the Norman conquest in England, judicial office was "communal" in character, and the courts could not be considered the exclusive tools of the King. Afterwards, the old communal courts were linked with the central curia, which performed multiple functions, and which was staffed by the King's men-his deputies by virtue of his commission. The causes brought before the curia were decided under the King's writ, making the King himself the "fountain of justice."12 Heretofore, the grant of office in medieval England was practically the same as a grant of land: it conferred an estate, so to speak, in the office, according to the terms of the grant. Many of the King's offices became hereditary by this process, and thus less useful to him. Accordingly, the functions of these hereditary offices were taken over by newer positions, such as justiciar and chancellor, which were filled by men of lower birth but who, because they were dependent on the King, could be entrusted with more power. The tenure of these new offices-which comprised much of the central curia-was at the pleasure of the King. ${ }^{13}$ Of course, officials appointed at the King's pleasure could be removed by him for any reason whatsoever. Those appointed during good behavior, which in effect conferred a life estate in the office,

\footnotetext{
${ }^{11}$ Wright, The Origins of the Separation of Powers in America, $\mathrm{r}_{3}$ EconomIn 169,179 (1933).

${ }^{12}$ Mcllwain, The Tenure of English Judges, 7 AM. Por. Scr. Rev. 217, 218 (1913). While not documented, this paper, prepared for oral presentation before a meeting of the Amercian Political Science Association, is highly readable and accurate in detail.

${ }^{13}$ Id. at 219.
} 
could be forced to forfeit their office for misconduct, real or manufactured; the character of the conduct, and whether or not the office would be forfeited, could be determined by the King's Bench under a writ of scire facias. ${ }^{14}$

The first major challenge to the practice of appointing judges at the King's pleasure came in 1628, when Charles I ordered Sir John Walter to surrender his patent as chief baron of the exchequer because he was dissatisfied with one of Walter's decisions. Walter refused, arguing that his tenure was based on good behavior, not on the King's pleasure, and that he should be removed only if a scire facias proceeding determined he had misbehaved. Embarrassed, Charles allowed Walter to keep his patent, his office, and his revenues, although the judge never again appeared in the court of the exchequer. Although Charles had given in somewhat to Walter, within the next decade he dismissed several other judges and set the stage for the Long Parliament of $x 640-4 I$ to demand that he appoint a committee to study the tenure of judges. The result was a petition to the King requesting that he substitute tenure during good behavior for tenure during pleasure. Charles complied. $^{15}$

Despite the concessions, English kings continued to dismiss judges sporadically during the next sixty years. This was especially true during the reigns of Charles II and James II, when the "transferrals and removals were many" and "passed all precedent and all decency."16 Finally, in I70r, Parliament passed the Act of Settlement, the principal statute dealing with judicial tenure in modern England and "the one substantially followed ever since."17 Among other things, it provided that:

Judges' commissions be made quamdiu se bene gesserit and their salaries ascertained and established but upon the Address of both Houses of Parliament it may be lawful to remove them. 18

Tenure during good behavior-an essential requisite for judicial independencehad become part of the British law, although it was timed not to take effect until after the death of the King and Princess Anne "and in default of issue of either." Thus, it was not until $I 760$ that the tenure of the sitting judges ceased to depend upon the pleasure of the reigning monarch. ${ }^{19}$ Even then, "their tenure was far more secure than it had been under the Stuarts, but they enjoyed at best a limited independence." ${ }^{20}$ Judges continued to be active politically well into the late eighteenth

\footnotetext{
${ }^{14}$ Ross, 'Good Behavior' of Federal Judges, I2 U. Kan. CiTY L. Rev. II9, I20 (1944).

${ }^{15}$ VI E. Foss, The Junges of England 372 (1857). In his brief biography, Foss recounts that after assuming the duties of chief baron, Walter "did not answer to the king's expectations. He was too independent and too honest to suit the royal will." Id. at 37I-72.

${ }^{10}$ T. Plucknett, A Concise History of the Common Law 60-6i (5th ed. x956). See also Mcllwain, stupra note 12 , at 223 .

${ }^{17}$ Mcllwain, supra note 12 , at 224.

${ }^{18} 12$ \& 13 William III, c. $2, \S 3$ (1700). See also The Eighteentf Century Constitution, I6881815, at 59 (E. Williams ed. I960).

${ }^{10}$ I George III, c. 23 (1760).

${ }^{20}$ Ziskind, Judicial Tenture in the American Constitution: English and American Precedents, I969 Sup. CT. Rev. 135, 137 .
} 
century, ${ }^{21}$ and they still could be removed upon address by both houses for any reason whatsoever. ${ }^{22}$

Nonetheless, the Act of Settlement established the basis for the modern English judicial system, and it has been observed that:

The net result of it all is that ... an English Judge holding by patent quamdiz se bene gesserit, like any other official so holding, may lose his office by judicial process under a writ of scire facias, if it appear that the conditions of the patent have not been fulfilled. Second, he may be impeached and removed from office by sentence of the house of lords, though this has not occurred for over a century. Third, the crown may remove him without any cause shown, after a joint address of the houses of parliament requesting it, but not otherwise. ${ }^{23}$

\section{B. Colonial Developments}

While the struggle for judicial independence was proceeding at a slow but steady pace in England, there was no comparable progress in the American colonies. For the most part, early colonial judges served at the pleasure of the royal governors, and except for Pennsylvania, no colonial assembly had the power to impeach a judge. ${ }^{24}$ However, the tendency during the later colonial period was to place some restrictions on the removal power of the governors, and longer tenure based on good behavior was established in several colonies. ${ }^{25}$ Then, in $\mathrm{I} 76 \mathrm{r}$, acting on advice of the Board of Trade, the King made tenure at royal pleasure, ostensibly "on ground that the state of learning in the colonies was so low that it was with difficulty that men could be found competent to administer the judicial offices."20 Later, in I772, George III established a fixed salary for the judges of the superior court of Massachusetts, thus preventing them from receiving their usual grants from the House of Representatives and the council and governor. This action aroused so much opposition that it has been credited with causing the complaint in the Declaration of Independence that George III "has made judges dependent upon his will alone for the payment of their salaries."27

Thus, due to the King's growing distrust of the colonies, judicial independence in America had taken a turn for the worse at the time of the Revolution, although it had been a goal of the colonists for some time, and despite their limited successes in promoting it:

One of the long-continued struggles of the assemblies was for judicial tenure during good behavior, a tenure much more conducive to judicial independence than that

\footnotetext{
${ }^{21}$ Plucknetr, supra note 16, at 248. Plucknett recites the activities of William Murray, Earl of Mansfield, who as Lord Chief Justice of the King's Bench remained in the House of Lords and, among other things, argued against repeal of the Stamp Act.

${ }^{22}$ W. Carpenter, Judicial Tenure in the United States I25 (1918).

${ }^{23}$ Mcllwain, supra note 12 , at 225.

24 Ziskind, stpra note 20, at 138 .

${ }^{25}$ Wright, supra note II, at 176 .

${ }^{26}$ CARPENTER, supra note 22, at 2-3.

${ }^{27} I d$. at 2.
} 
during the pleasure of the executive. Despite the opposition of the Crown, extending even to the removal of one governor who failed to veto such an act, the assemblies managed to establish the longer tenure in several colonies. ${ }^{28}$

After 1776 , the states developed constitutions containing various prohibitions of executive control over the judiciary, and these documents provided some powerful precedents for the founding fathers when they met eleven years later. Some states, such as Connecticut, retained basically the same form of government as had existed prior to independence. There was no uniform standard to be followed by those states which drafted new constitutions, and naturally the new governing documents revealed no accepted method of selecting judges or granting them tenure. ${ }^{29}$ For example, New York granted tenure to its supreme court judges during good behavior, while New Jersey gave them seven-year terms. ${ }^{30}$ In most states, as in the abortive Articles of Confederation, the legislature was the dominant power in government under the early state constitutions, playing a leading role in the choice and removal of judges in all but a few states where it was limited to impeachment of judges for misconduct. ${ }^{31}$ James Madison observed at the Philadelphia convention that:

$[E]$ xperience in all states has evinced a powerful tendency in the legislature to absorb all power into its vortex. This was the real source of danger to the American [state] Constitutions; and suggested the necessity of giving every defensive authority to the other departments that was consistent with republican principles. ${ }^{32}$

The Bill of Rights of the Massachusetts Constitution of 1780 took a position substantially like Madison's when it stated unequivocally that:

It is essential to the preservation of the rights of every individual, his life, liberty, property, and character, that there be an impartial interpretation of the laws, and administration of justice. It is the right of every citizen to be tried by judges as free, impartial and independent as the lot of humanity will admit. It is therefore not only the best policy, but for the security of the rights of the people, and of every citizen, that judges hold their office as long as they behave themselves well; and that they should have honourable salaries ascertained and established by standing laws. ${ }^{33}$

That same Massachusetts Constitution also provided a more specific clause delineating its separation of powers doctrine:

In the government of this commonwealth, the legislative department shall never exercise the executive and judicial powers, or either of them; the executive shall

\footnotetext{
${ }^{28}$ Wright, stpra note $\mathrm{r} x$, at $\mathrm{I77}$.

${ }^{20}$ Ziskind, stupra note 20, at $\mathrm{r} 39$. This source gives a rather detailed survey of the judicial systems initially used by each of the new states.

${ }^{30} \mathrm{Id}$. at $\mathbf{x} 40$.

${ }^{82}$ Id. at $138-39$.

${ }^{32}$ Quoted in F. Green, Constttuttonal Development in the South Atlantic States, I776-I860, at IO3 $_{\text {(I930). }}$

${ }^{33}$ The Federal and State Consttututions, Coloniad Charters and Other Organic Laws of the UntTed States, art. 29, at 960 (B. Poore ed. I878).
} 
never exercise the legislative and judicial powers, or either of them; the judicial shall never exercise the legislative and executive powers, or either of them; to the end that it may be a government of laws, and not of men. ${ }^{34}$

Despite Massachusetts' provision for separation of powers and a more independent judiciary, Madison said later in The Federalist, No. 47, that:

If we look into the constitutions of the several States we find that, notwithstanding the emphatical and, in some instances, the unqualified terms in which this axiom has been laid down, there is not a single instance in which the several departments of power have been kept absolutely separate and distinct.

Thus it is clear that the founders arrived at Philadelphia familiar with English and American precedents of separated powers and judicial independence. From English history and from their knowledge of the political philosophers, they had gained familiarity with and respect for the principle of judicial independence. From their own colonial experience and from their state constitutions, they had learned the importance of incorporating the doctrine in the governing documents in order to assure the fair administration of justice.

\section{The Constitutional Convention}

John Randolph of Virginia offered the initial proposal relating to the judicial branch at the Constitutional Convention; Randolph came from a state where the legislature had been dominant. His proposal provided for judges to be chosen by the national legislature, and to "hold their offices during good behavior." Charles Pinckney of South Carolina submitted an alternative proposal on the same day which also provided for judicial tenure during good behavior. ${ }^{36}$ Hamilton, whose primary concern was the establishment of a strong executive, later suggested the inclusion of a judiciary article providing for a supreme court with justices serving during good behavior and removable only by conviction on impeachment for some crime or misdemeanor. ${ }^{37}$

When the judiciary article reached the floor of the Convention for debate, an attempt was made by John Dickinson of Delaware to install address as a means of removing judges. After the words "good behavior" would have been inserted the words "provided that they may be removed by the Executive on the application [by] the Senate and House of Representatives." Gouverneur Morris thought the provision would be a "contradiction in terms," since it would subject judges who would be serving during good behavior to removal without a trial. Another objection was made by Randolph, who "opposed the motion as weakening too much the independence of the Judges." The proposal was defeated seven to one, with three

\footnotetext{
s4 Id., art. 30 , at 960 .

${ }^{35}$ I M. Farrand, The Records of the Federal Convention of 1787, at 2x (1934).

${ }^{36}$ III id. at 600 .

${ }^{37}$ Id. at 628 .
} 
states absent, and removal by address was specifically rejected by the founding fathers. ${ }^{38}$ The tenure of federal judges was thus established as during good behavior subject only to impeachment by the House of Representatives and conviction by the Senate sitting as a jury, and was embodied in section I of article III as finally adopted by the framers:

The judicial Power of the United States, shall be vested in one supreme Court, and in such inferior Courts as the Congress may from time to time ordain and establish. The Judges, both of the supreme and inferior Courts, shall hold their Offices during good Behavior, and shall, at stated Times, receive for their services, a Compensation, which shall not be diminished during their Continuance in Office.

The framers did not include a specific clause in the Constitution separating the powers of government among the three branches. However, they did classify the powers and assign them to their respective departments. In addition to article III, which assigned the judiciary power, article I, section I provided that "All legislative Powers herein granted shall be vested in a Congress of the United States ..." and article II, section I specified that "The executive Power shall be vested in a President of the United States of America."

An early criticism of the Constitution was that it did not specifically separate the powers in accord with Montesquieu's maxim but rather that it actually meshed some of the powers. ${ }^{39}$ The overlapping-popularly described as the system of checks and balances-takes several forms: for instance, the power of appointment is given to the executive, but with the advice and consent of the Senate, and impeachment, which in essence is a judicial function, was given to the Congress. ${ }^{40}$ However confusing such a system may seem, it has served a valuable purpose, and was ably defended by Madison in The Federalist, No. 47:

The magistrate in whom the whole executive power resides cannot of himself make a law, though he can put a negative on every law; nor administer justice in person, though he has the appointment of those who do administer it. The judges can exercise no executive prerogative, though they are shoots from the executive stock; nor any legislative function, though they may be advised by the legislative councils. The entire legislature can perform no judiciary act, though by the joint act of two of its branches the judges may be removed from their offices, and though one of its branches is possessed of the judicial power of the last resort. The entire legislature, again, can exercise no executive prerogative, though one of its branches constitutes the supreme executive magistry, and another, on the impeachment of the third, can try and condemn all the subordinate officers in the executive department.

${ }^{38}$ II id. at $428-29$.

${ }^{30}$ Fairlie, supra note 3, at 398 . Madison, in The Federalist, No. 47, states that "One of the principal objections inculcated by the more respectable adversaries to the Constitution is its supposed violation of the political maxim that the legislative, executive, and judiciary departments ought to be separate and distinct."

${ }^{\circ 0}$ See id. at 402-03. 
The accumulation of all powers, legislative, executive and judiciary, in the same hands, whether of one, a few, or many, and whether hereditary, self-appointed, or elective, may justly be pronounced the very definition of tyranny.

Another complaint lodged against the new Constitution while it was before the states for ratification was the absence of a specific method of removing judges. The opponents of ratification recognized that the Constitution made provision by its impeachment process for the removal of judges from their judicial offices for "Treason, Bribery, or other high Crimes and Misdemeanors" (article II, section 4). They complained of the Constitution, however, because it made no provision for removal of judges for mental infirmities arising out of age or other causes. The founding fathers omitted a provision for removal on such grounds because, as Hamilton stated in The Federalist, No. 79, it "would much oftener give scope to personal and party attachments and enmities than advance the interests of justice or the public good." Said Hamilton:

The want of a provision for removing the judges on account of inability has been a subject of complaint. But all considerate men will be sensible that such a provision would either not be practiced upon or would be more liable to abuse than calculated to answer any good purpose. The mensuration of the faculties of the mind, has, I believe, no place in the catalogue of known arts. An attempt to fix the boundary between the regions of ability and inability would much oftener give scope to personal and party attachments and enmities than advance the interests of justice or the public good. The result, except in the case of insanity, must for the most part be arbitrary; and insanity, without any formal or express provision, may be safely pronounced to be a virtual disqualification.

Hamilton went on in The Federalist, No. 79, to declare that investigations into the abilities of a judge "must forever be vague and dangerous." The early New York state constitution, he said, avoided such investigations by providing that all judges retire at sixty years of age. Hamilton added:

I believe there are few at present who do not disapprove of this provision. There is no station in relation to which it is less proper than to that of a judge. The deliberating and comparing faculties generally preserve their strength much beyond that period in men who survive it; and when, in addition to this circumstance, we consider how few there are who outlive the season of intellectual vigor and how improbable it is that any considerable portion of the bench, whether more or less numerous, should be in such a situation at the same time, we shall be ready to conclude that limitations of this sort have little to recommend them in a republic where fortunes are not affluent and pensions not expedient, the dismission of men from stations in which they have served their country long and usefully, on which they depend for subsistence, and from which it will be too late to resort to any other occupation for livelihood, ought to have some better apology to humanity than is to be found in the imaginary danger of a superannuated bench. 
Earlier, in The Federalist, No. 78 , Hamilton defended the appointment of judges for tenure during good behavior, which he considered "the citadel of the public justice and the public security." He continued:

According to the plan of the convention, all judges who may be appointed by the United States are to hold their offices during good behavior; which is most conformable to the most approved of State constitutions. . . . The standards of good behavior for the continuance in office of the judicial magistracy is certainly one of the most valuable of the modern improvements in the practice of government. In a monarchy it is an excellent barrier to the despotism of the prince; in a republic it is no less excellent barrier to the encroachments and oppressions of the representative body. And it is the best expedient which can be devised in any government to secure a steady, upright, and impartial administration of the laws.

In The Federalist, No. 5I, Madison commented on the importance of the judiciary's independence from the appointing authority:

In order to lay a due foundation for that separate and distinct exercise of the different powers of government, which to a certain extent is admitted on all hands to be essential to the preservation of liberty, it is evident that each department should have a will of its own; and consequently should be so constituted that the members of each should have as little agency as possible in the appointment of the members of the others .... In the constitution of the judiciary department in particular, it might be inexpedient to insist rigorously on the principle: first, because peculiar qualifications being essential in the members, the primary consideration ought to be to select that mode of choice which best secures these qualifications; secondly, because the permanent tenure by which the appointments are held in that department must soon destroy all sense of dependence on the authority conferring them. It is equally evident that members of each department should be as little dependent as possible on those of the others for the emoluments annexed to their offices. Were the executive magistrate, or the judges, not independent of the legislature in the particular, their independence in every other would be merely nominal.

The well-known rule of construction that the expression of one thing is the exclusion of another compels the conclusion that the founding fathers intended that no federal judge should be removed from office except through the impeachment process. Hamilton justified the purpose of the framers on this score when he said in The Federalist, No. 79:

The precautions for [judges'] responsibility are comprised in the article respecting impeachments... This is the only provision on the point which is consistent with the necessary independence of the judicial character, and is the only one which we find in our own Constitution in respect to our own judges.

$$
\text { D. The Congress of } 1789
$$

The first Congress meeting under the new Constitution promptly passed the Judiciary Act of 1789 , which established the Supreme Court and a federal district 
court in each state. ${ }^{41}$ It also passed a law making it a crime for a judicial officer to accept a bribe, and, on conviction, disqualifying him from holding any office of honor, trust, or profit with the United States government. ${ }^{42}$ The first of these acts set the tone of the federal judiciary and created a general structure which has been retained, with expansion and revision, to the present. Although the latter has been interpreted in some quarters as an early attempt to place some limit on the activities of federal judges outside the impeachment process, the statute has never been enforced. 43

During debate on the Judiciary Act of 1789 , Congressman Smith of South Carolina counseled his colleagues that it would not be easy to alter the federal system once it was established:

The judges are to hold their commissions during good behavior, and after they are appointed they are removable only by impeachment; in consequence the system must be a permanent one. ${ }^{44}$

\section{E. The Jeffersonian Democrats}

The federal judiciary established by the Act of 1789 remained essentially intact until the Federalists lost the election of $x 800$. Before they lost control of the administration and Congress early the next year, the Federalists established a number of new judgeships by passing the Judiciary Act of $180{ }^{45}$ and President John Adams appointed members of his party to the positions during the last hours of his administration. ${ }^{46}$ When the Jeffersonian Democrats took office shortly thereafter, they proceeded to repeal the Act of $180 \mathrm{or}$, thereby setting off a monumental debate on the powers of Congress to "undo what it had done" to the federal judiciary. ${ }^{47}$

Three years later, the Democrats took another swipe at the courts, this time with an attempt to impeach and convict the Federalist Associate Justice of the Supreme Court, Samuel Chase. He was charged with misconduct while holding a trial for sedition. The accusations obviously were politically motivated. Although Chase was impeached by the House and the effort received a majority vote in the Senate, it failed for lack of the necessary two-thirds vote. However, the Jeffersonian Democrats managed in that same year to bring about the first successful impeachment, conviction, and removal of a federal judge-John Pickering of New Hamp-

\footnotetext{
11 Judiciary Act of 1789 , I Stat. 73 .

4 Act of April 30, I790, ch. I9, §2I, I Stat. II7.

43 Testimony of Peter G. Fish at Hearings on The Independence of Federal Judges Before the Stubcomm. on Separation of Powers of the Senate Comm. on the Judiciary, 91st Cong., 2d Sess. (1970). (Unpublished). These hearings are discussed infra.

"I Annals of Cong. 860 ( 1789 ).

4 Act of Feb. 13, I80I, ch. 4, 2 Stat. 89.

${ }^{40}$ CARPENTER, supra note 22, at 55 .

${ }^{47}$ Kurland, The Constitution and the Tenure of Federal Judges: Some Notes from History, $36 \mathrm{U}$. Chr. L. Rev. 665, 67I (1969). Professor Kurland's article is an excellent review of the debate and of other attempts to install legislative limits on the tenure and independence of federal judges.
} 
shire, who was charged with violations of statute, conducting court while intoxicated, and blasphemy on the bench. ${ }^{48}$

\section{F. The Court Packing Debate}

Attempts to remove judges by means other than impeachment gained renewed impetus in the r930s when President Franklin D. Roosevelt attempted to "pack" the Supreme Court, and legislation was sponsored by Representative Hatton Sumners of Texas, chairman of the House Judiciary Committee, which would have created a panel to rule on the fitness of federal judges. ${ }^{49}$ The efforts sparked a great debate over the constitutionality of alternative methods of removal. The basic argument on behalf of constitutionality was propounded by Professor Burke Shartel, whose treatise ${ }^{50}$ was written a few years before the debate and is still relied upon extensively by those who believe there can be some method of removal other than impeachment under the Constitution. Taking the opposing view was a federal district judge and legal scholar, the late Merrill E. Otis. ${ }^{51}$ The debate centered around the legislative proposal to create a tribunal to rule on the fitness of federal judges alluded to above.

Shartel took the position that impeachment was designed to restrict the power of the Congress over judges, not that of the judicial branch over its own members. ${ }^{52}$ He argued that the removal of a judge involves a justiciable dispute and as such can be handled by the judicial branch. Admitting that the separation of powers doctrine precludes executive removal, Shartel asserted that legislative removal is possible only through impeachment, bills of attainder having been rejected at the Constitutional Convention. He said:

The separation of powers doctrine stands in the way of any legislative removal of executive and judicial officers, except as such removal is expressly authorized in one form-impeachment. ${ }^{53}$

\footnotetext{
${ }^{48}$ For a concise resume of impeachments, see The Kelly Memorandum, II6 Cong. REc. H8039 (daily ed. Aug. 10, 1970). Including Chase and Pickering, there have been a total of nine impeachments, based on various charges. In 1830 , James $H$. Peck of Missouri was impeached, but not convicted, for punishing for contempt a lawyer who was critical of one of his opinions; in 1862 , West H. Humphries was impeached and convicted for aiding in the secession of Tennessee and serving as a Confederate judge; in I904, Charles Swayne of Florida was acquitted on charges involving false expense account claims, misuse of a receivership for personal gain and living outside his district; in 19I2, Robert W. Archbald was convicted and removed from the Commerce Court on charges of using his position to secure business favors; in 1926 , George W. English of Illinois resigned in the face of accusations that he had abused his power by suspending and disbarring two attorneys, and that he had used his office for personal gain; in 1936, Harold Louderback of California was acquitted of charges that he used his office to enrich his friends; and, also in 1936 , Halsted L. Ritter was convicted and removed on a charge that he had received kickbacks from legal fees awarded his former law partner.

${ }^{\circ} \mathrm{S}$. 4527 and H.R. Res. 2271, 75th Cong., rst Sess. (1936). Both bills are reprinted in full in Otis, A Proposed Tribunal: Is It Constitutional?, 7 U. KaN. CiTY L. Rev. 3, 10-12 (1938).

${ }^{\circ}$ Shartel, Federal Judges-Appointment, Supervision, and Removal-Some Possibilities Under the Constitution, 28 Micr. L. Rev. 8 jo (1930).

${ }^{82}$ Otis, supra note 49.

va Shartel, supra note 50 , at 894 .

cs Id. at 88r.
} 
Shartel believed that methods of judicial removal-scire facias and quo warrantowere still operative, enabling the judicial branch (presumably the Supreme Court or some other body of judges) to remove members of the inferior courts.

Judge Otis answered Shartel with a question of his own:

The Constitution does separate our government into three independent branches.

But does not the independence of the judicial branch attach as much to the judges of the inferior courts as it does to the justices of the highest court? ${ }^{\text {tu }}$

He convincingly pointed out the absence in the Convention debates of any other method of removal; the fact that the Constitution makes no distinctions between judges, whether they be supreme or inferior-they are all to hold office "during good behavior"; and that the Constitution fixes the term of a judge as life, leaving the Congress no more power to alter that term than it has to alter the term of the President or Vice President.

Otis also carefully analyzed the word "sole" used in describing the powers of impeachment:

It is well known, and often has it been said by the highest courts, that every word of the Constitution was intended to have significance. If that is true of any word, it is especially true of the strong word-"sole."

The Framers certainly would not have been so meticulous in the use of words, so careful to use this particular strong word in the vesting of the impeachment power, unless they had in mind either, (a), that in the past in English law the power to charge misconduct against an officer for the purpose of securing his removal from office had been exercised by some body or official other than the House of Commons, or, (b), that in after years some one might conceive that the power might be exercised by some other body or official than the House of Representatives. The word "sole" was used to make it clear to all forever that, in the American system, no significance should be given to any English precedent, if there were any, whereby the power to charge misconduct for the purpose of obtaining removal of a civil officer from office, was held to be lodged in any other than that legislative body directly representing the whole people..$^{65}$

Shartel based his argument on the continued existence of a proceeding like scire facias, and if Judge Otis did not demolish it, another scholar did when she said:

The clearest rejection of Shartel's argument lies in the fact that no colonial or state constitution provided for such a use of scire facias, nor was a proposal made to include it during the Constitutional Convention. Even in the unreformed common law, there was a distinction between precedents and fossils. ${ }^{56}$

The arguments put forward during the 1930s, of course, came and went with the unsuccessful attempts to pack the court and to establish the judicial oversight

\footnotetext{
52 Otis, supra note 49, at 17.

${ }^{85} I d$. at 25-26.

${ }^{50}$ Ziskind, supra note 20 , at 138 .
} 
tribunal. And so, for the most part, did attempts to erode the independence of our federal judges, at least for thirty years.

\section{II}

\section{COMMENTARY}

I have attempted from the foregoing sketchy treatment of the historical basis of judicial independence to show that the concept was a sine qua non to the men who drafted the United States Constitution. Because of the limitations of space and time, it was not possible for me to delve into the detail that would be appropriate and that would even more strongly support my thesis that judicial independence is the strongest safeguard against the exercise of tyrannical power by men who want to live above the law, rather than under it. The separation of powers concept as understood by the founding fathers assumed the existence of a judicial system free from outside influence of whatever kind and from whatever source, and further assumed that each individual judge would be free from coercion even from his own brethren.

The founding fathers, in establishing our national government, reflected clearly the lessons they had absorbed concerning the history of man's struggle to be free from tyranny. They knew that those entrusted with governmental powers are susceptible to the disease of tyrants-to what George Washington described in his Farewell Address as the "love of power and proneness to abuse it." Th7 They realized that the powers of public officers should be defined by laws which they, as well as the people, are obliged to obey, and that liberty demands control by constant and uniformly enforced laws rather than by the arbitrary and inconstant whims of willful men.

They recognized the inalterable truth expressed by Thomas Hobbes, when he said that freedom is "political power divided into small fragments," reason they diffused national power among three branches of government, each charged with specific responsibilities and each likewise precluded from exercising those powers bestowed upon the other two branches. Because they had suffered the burdens of tyranny, the founding fathers very carefully provided for a federal judiciary that would operate completely independent of everything except the Constitution.

To my mind, an independent judiciary is perhaps the most essential characteristic of a free society. From long experience as a practicing attorney, a trial judge, an appellate judge, and now a legislator, I have had ample opportunity to observe and appreciate the safeguards embodied in the separation of powers doctrine so wisely formulated by our forefathers.

Unfortunately, the events of recent years have created an aura of crisis in many sectors of our society, and in their haste to set right situations deemed disastrous,

\footnotetext{
${ }^{87}$ I Messages and Papers of the Presidents 21 (J. Richardson ed. 1897 ).

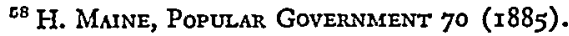


leaders in all three branches of the government have proposed solutions ultimately inimical to the constitutional safeguards so carefully formulated by the founding fathers. The principle of judicial independence has been gravely endangered as a result of this "crisis" approach to solving our problems. Beyond doubt during this era of social upheaval, there is a rather extraordinary lack of confidence in many of our governmental institutions, including the judiciary. Hence, it is not surprising that some deeply concerned persons would emulate the example of Sampson, who, in his blind zeal, destroyed the pillars on which the temple rested. There are now pending before the Congress well over two dozen measures designed to place new restrictions on federal judges. In many instances these measures represent a direct assault upon the principle of judicial independence. Some of them are directed toward limiting the non-judicial activities of federal judges, while others are designed to provide means of disciplining the federal judiciary.

Because of the controversy over the proper role of the judiciary, the Senate Judiciary Subcommittee on Separation of Powers, ${ }^{50}$ of which I am chairman, conducted two series of hearings into the principle of judicial independence. The first series of hearings undertook to investigate the many pertinent questions about the non-judicial activities of judges which were raised in the wake of the Fortas resignation. Thus, on July I4, I5, and I6, and September 30, 1969, the Subcommittee heard testimony from an impressive list of expert witnesses ranging from former Supreme Court Justices Tom C. Clark, Arthur J. Goldberg, and Stanley Reed, to former Secretary of State Dean Acheson. The hearings emphasized the general ramifications of proposed limitations on the extra-judicial activities of federal judges rather than focusing on any single piece of proposed legislation. The hearings failed to produce any consensus on precisely what constitutes an improper outside activity for federal judges, although there was general agreement that the Congress should be very reluctant to pass all-encompassing legislation which might result in undue restrictions. ${ }^{\text {Bo }}$

Because of the continuing clamor both in the press and in the Congress, the Subcommittee this spring devoted four days of hearings to the independence of

\footnotetext{
${ }^{50}$ The Subcommittee on Separation of Powers originated under S. Res. 305, sponsored by Senators Dirksen and Mansfield in the 89th Congress, $2 d$ Session. It is authorized to "make a full and complcte study of the separation of powers between the executive, judicial and legislative branches of Government provided by the Constitution, the manner in which such power has been excreised by cach branch and the extent if any to which any branch or branches of the Government may have encroached upon the powers, functions, and duties vested in any other branch by the Constitution of the United States." Present membership consists of Sam J. Ervin, Jr., North Carolina, Chairman; John L. McClellan, Arkansas; Quentin N. Burdick, North Dakota; Charles McC. Mathias, Jr., Maryland; and Robert P. Griffin, Michigan.

${ }^{\circ}$ Hearings on Nonjudicial Activities of Supreme Cout Justices and Other Federal Judges Before the Subcomm. on Separation of Powers of the Senate Comm. on the Judiciary, gist Cong., 1st Sess. (1969). (Unpublished.) These hearings are soon to be published by the Subcommittee, and should prove of great value to scholars who wish to study contemporary viewpoints on judicial independence.

The Subcommittee, at this writing, is in the process of drafting a proposed set of suggestions regarding what constitutes acceptable outside activities of federal judges. I should like to emphasize that these would only be suggestions for possible use by the federal judiciary; they will not under any circumstances be considered legislative proposals.
} 
federal judges. These hearings, conducted on April 7 and 9, and May 7 and 8, r970, were concerned with the roles of the Judicial Conference of the United States and the judicial councils of the various circuits as they relate to the independence of federal judges, and with certain legislative proposals introduced to expand the powers of judges to oversee the judicial activities of their brethren. ${ }^{61}$

During this second set of hearings, the Subcommittee paid particular attention to Senate Bill 1506, introduced in the First Session of the Ninety-first Congress by Senator Joseph Tydings "to provide for improvement in the administration of courts of the United States . ..." It is cited as the Judical Reform Act. ${ }^{62}$

Title I of the Tydings bill would create a Commission on Judicial Disabilities and Tenure, consisting of judges appointed by the Chief Justice, and empowered to investigate charges of misconduct and to recommend to the Judicial Conference the removal of a federal judge. In turn, the Conference would have the power to remove the judge, subject to appeal to the Supreme Court by certiorari. Complaints could be brought by "any person" against any federal judge, and the grounds for removal could range from disability to conflict of interest. In effect, title I would provide a means for removing federal judges from office without compliance with the constitutional mandate that nothing except impeachment and conviction can be used for that purpose. Obviously, possible objections to title I are manifold. Not only does it raise serious constitutional questions, but its language presents intense problems of interpretations.

My colleague, Senator Tydings, of course, is concerned with improving the machinery for the administration of justice. I share that concern, as all of us must in this period when there are unprecedented backlogs in our courts, when justice in one district may be swifter than in another, and when public respect for our

${ }^{01}$ Hearings, supra note 43. These hearings also are being prepared by the Subcommittee for publication and will be available soon.

${ }^{22}$ II5 ConG. REc. S2732-45. S. I506 and accompanying bills, S. I507 through S. I516, 91st Cong., Ist Sess. (I969), are printed at this point in the Congressional Record. The pertinent provisions of S. I506 have been described by the Legislative Reference Service as follows:

Judicial Reform Act-Title I: Commission on Judicial Disabilities and Tentre-Establishes within the judicial branch of the Government a Commission on Judicial Disabilities and Tenure composed of five members. Requires each member be a judge of the United States who is in regular active service. Requires the Commission, at all times, to include at least two district judges, and two circuit judges. Provides that all members be assigned to the Commission by the Chief Justice of the Supreme Court [sic]. Makes the term of the Commission four years.

Provides that the Commission shall promote the honorable and efficient administration of justice in the courts of the United States. Permits it to act to retire or remove a judge only after an investigation and formal hearing in accordance with the requirements of due process. Provides that a decision to remove a judge for misconduct shall be subject to review by the Judicial Conference and ultimately by the Supreme Court by certiorari. Makes such proceedings confidential.

Enables the Commission to undertake an investigation of a judge [sic] physical or mental fitness upon a report of any person. Gives the Commission necessary powers such as the subpoena power, depositions, etc. Authorizes the payment of fees and mileage of vitnesses and provides that U.S. marshals shall serve process and execute orders for the Commission.

See Digest of Public General Bills and Resolutions, grst Cong., ist Sess., Legrs. ReF. Serv. A-97 (I969). 
judicial system is at such a low ebb that any misstep by an individual judge may be attributed in the public mind to the entire federal judiciary. However, commissions such as the one embodied in the Tydings bill will not solve these problems, for they would be empowered to deal with the results, not the causes of our problems. ${ }^{03}$

Virtually all of the witnesses in the last hearings, most of whom were federal judges, conveyed to the Subcommittee in the strongest possible terms that their legal research and long experience convinced them that measures such as Senate Bill I506 are not only patently unconstitutional, but could serve as tools for disgruntled litigants to disrupt the orderly process of the administration of justice.

Following the hearings, the Subcommittee sent a letter to every federal district judge in the United States soliciting his views on the Tydings bill. We felt this information would be particularly telling since the district judges would be most involved with and affected by the measure. Of more than a hundred responses received to date, only one indicated support for this bill. ${ }^{64}$ Most of the judges responding were very specific in their objections, emphasizing the questionable constitutionality of the measure, the unreasonable burden it would place on federal judges, and the serious, if not fatal, damage it would do to the principle of an independent judiciary.

One judge reflected the feelings of his colleagues:

Complete independence is a basic sine qua non for effective judges. The question of whether this independence can ever be restricted at all without doing more harm than good becomes more difficult philosophically with more careful study and analysis.... It seems to me that if the problem is put into proper perspective, and the sins of the very few judges who are lazy, or who fail to recognize their own weakness, are viewed, not in isolation, but in proportion to those judges who do not abuse their independence, but utilize it to give the fairest and promptest justice that they can, there appears no real reason to resort to expedients of doubtful constitutionality, and fraught with the likelihood of being in themselves more dangerous than the evils against which they are directed.

A second judge predicted another danger, harassment by disgruntled litigants:

The threats to judicial independence found in the provisions of the bill are real. Congress and not other judges should determine whether or not a judge should be removed from office. Also, the harassment that would be put into play against a judge by disgruntled litigants would be both burdensome and insulting to such judge. A disgruntled litigant has his right of appeal from a judgment adverse to him, and in these days such appeal is being made more and more easy to accomplish.

\section{As a third judge pointed out:}

\footnotetext{
${ }^{03}$ S. I506 may be considered typical of several bills directed toward the same goal; however, it has received by far the greatest publicity and might be considered the most controversial. I would suggest that it would be more helpful to enact measures such as S. 3936, 9rst Cong., 2d Sess., a bill I introduced on June 9,1970 , to implement the constitutional mandate for speedy trials in the federal courts.

of The full text of these letters will be reproduced when the hearings are published.
} 
The Founding Fathers manifestly intended to make it very difficult to remove federal judges. This fact has been fundamental in permitting judges the independence to accord justice without favoritism and patronism. This beneficent aspect of the federal judiciary will be overthrown if Title I, S. 1506 were to become law.

While a good portion of the Subcommittee's second round of hearings was devoted to the Judicial Conference of the United States ${ }^{65}$ and the judicial councils of the circuits, ${ }^{66}$ the limitations of time and space preclude any detailed discussion in this paper of the capacity of these two bodies to infringe upon independence. Suffice it to say that my reading of the legislative history establishing the two bodies clearly convinces me that Congress intended them merely to be housekeeping bodies with no power whatsoever to discipline any federal judge for the omission or commission of any act. The founding fathers assigned that task to Congress. Judicial independence can just as easily be eroded by powerful hierarchies within the judiciary itself as by outside pressures from the legislative and executive branches of the government. Certain activities of the councils make it clear that their powers and functions should be more clearly defined. The issue was raised but was left unanswered in the two cases of Chandler v. Judicial Council of the Tenth Circuit. ${ }^{67}$ In the Chandler episode, the Judicial Council of the Tenth Circuit decided that it would discipline Judge Chandler by ordering him to take no action on cases pending before him, and by refusing to assign him any other cases. Judge Chandler, believing that this was tantamount to an unconstitutional impeachment and conviction by the Tenth Circuit, twice sought to have the Supreme Court pass on the issue. However, the Supreme Court in both instances refused the opportunity to establish legal precedent for the constitutional principle that only Congress can remove a federal judge. I agree with Mr. Justice Black, who in the first Chandler case declared:

This is clearly and simply a proceeding by circuit judges to inquire into the fitness of a district judge to hold his office and to remove him if they so desire. I do not believe Congress could, even if it wished, vest any such power in the circuit judges.

One of the great advances made in the structure of government by our Constitution was its provision for an independent judiciary-for judges who could do their duty as they saw it without having to account to superior court judges or to anyone else except the Senate sitting as a court of impeachment. ${ }^{68}$

In the second Chandler case, the Court again refused to face the issue; instead it held that Judge Chandler had failed to make a "case for the extraordinary relief of mandamus or prohibition." ${ }^{\text {"89 }}$

Mr. Justice Black in the second Chandler case aptly expressed my opinion of the

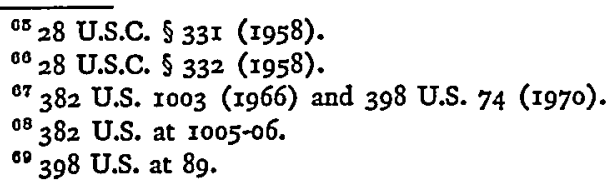


constitutionality of the actions taken by the Judicial Council of the Tenth Circuit when he said:

What is involved here is simply a blatant effort on the part of the Council through concerted action to make Judge Chandler a "second-class judge," depriving him of the full power of his office and the right to share equally with all other federal judges in the privileges and responsibilities of the Federal judiciary. I am unable to find in our Constitution or in any statute any authority whatever for judges to arrogate to themselves and to exercise such powers. Judge Chandler, like every other federal judge including the Justices of this Court, is subject to removal from office only by the constitutionally prescribed mode of impeachment. ${ }^{70}$

Under no circumstances would I wish to suggest that there are no abuses within the federal judiciary, or that there is no room for improvement either in the quality of the judges appointed to the federal bench or of the system under which they operate. However, I do believe that such legislative proposals as that embodied in the Tydings bill and such heavy-handed operations of the judicial hierarchy as is reflected in the Chandler incident represent wrong approaches to problems which may or may not exist. We all know that no perfect judicial system can be devised by the mind of man, and it would be sheer folly to cast away the constitutional protection we now have in a vain attempt to create such a perfect system. My reading of the Constitution and of the history surrounding its drafting convinces me that there is not a word or clause anywhere in that great document that would give any one of the three branches of government the power to remove federal judges except through the admittedly cumbersome process of impeachment, and there are ways through which the Congress could streamline that process without running afoul of the constitutional mandate. ${ }^{71}$

While there may be steps available to modernize and make more efficient the impeachment process, we must heed the warning Professor Philip B. Kurland, one of the country's noted constitutional authorities and the Chief Consultant to the Subcommittee on Separation of Powers, who said, "it should be kept in mind that

\footnotetext{
${ }^{70} I d$. at $\mathrm{r}_{42}$.

7 One such method has been suggested by Professor Preble Stolz of the University of California at Berkeley, who appeared before the Separation of Powers Subcommittee during its second series of hearings on judicial independence. Both there and in an excellent article entitled Disciplining Federal Judges: Is Impeachment Hopeless?, 57 CaLIF. L. Rev. 659 (I969), he recommended that the impcachment process be modernized and streamlined so that it can work more efficiently, while climinating political considerations to the maximum extent possible. This could be done by the House and Senate within the constitutional confines of impeachment. Professor Stolz suggests that the House name a Bipartisan Committee on Judicial Fitness with its own professional staff to assist it in reviewing the work of the judiciary and investigating allegations against federal judges. The Senate would appoint masters to conduct formal evidentiary hearings and prepare proposed findings of fact and conclusions of law which would be the basis of argument and decision in the Senate.

Senator Robert P. Griffin of Michigan made a similar suggestion during the first series of hearings mentioned above: "At this time, the only way to remove a Federal judge is by impeachment. It could be made much more effective than it is. That is one point I would like to stress. If Congress were to lay down standards and provide better machinery for determining what constitutes a 'high misdemeanor' or 'good behaviour,' impeachment could be a far more meaningful deterrent."
} 
tools created by the well-intentioned for beneficent uses may fall into less worthy hands to be used for less appropriate ends."72

The founding fathers knew that the form of government they established would not create a judiciary composed of judicial angels who could do no wrong. They knew that the activities of a few judges might handicap the operation of the system, but at the same time they realized that individual liberty is best protected by an independent judiciary composed of judges who are subject to the Constitution alone. They had learned the lesson of history, and attempted to build safeguards into our system which would prevent its repetition. We must not reject their wisdom-and destroy our own freedoms-by regarding the Constitution they drafted as a piece of ancient parchment which can be folded and rearranged to suit the whims of individual men.

\footnotetext{
${ }^{12}$ Kurland, supra note 47 , at 666.
} 